\title{
Lycopene and ß-carotene protect in vivo iron-induced oxidative stress damage in rat prostate
}

H.R. Matos ${ }^{3}$, S.A. Marques ${ }^{1}$, O.F. Gomes ${ }^{1}$, A.A. Silva ${ }^{2}$,

J.C. Heimann², P. Di Mascio ${ }^{1}$ and M.H.G. Medeiros ${ }^{1}$

\author{
'Departamento de Bioquímica, Instituto de Química, \\ 2Departamento de Clínica Médica-Nefrologia, Faculdade de Medicina, \\ Universidade de São Paulo, São Paulo, SP, Brasil \\ ${ }^{3}$ Departamento de Fisiologia, Universidade Federal de Sergipe, São Cristóvão, \\ SE, Brasil
}

\section{Correspondence}

M.H.G. Medeiros

Departamento de Bioquímica

Instituto de Química, USP

Av. Prof. Lineu Prestes, 748

05508-900 São Paulo, SP

Brasil

Fax: +55-11-3815-5579

E-mail: mhgdmede@iq.usp.br

Research supported by FAPESP, CNPq, and PRONEX/FINEP.

P. Di Mascio is the recipient of a

fellowship from the John Simon

Memorial Guggenheim Foundation.

Received January 31, 2005 Accepted October 27, 2005

\begin{abstract}
It has been suggested that iron overload may be carcinogenic. In the present study, we evaluated the effect of plasma and prostate carotenoid concentration on oxidative DNA damage in 12-week-old Wistar rats treated with intraperitoneal (ip) ferric nitrilotriacetate (Fe-NTA) (10 mg Fe/kg). Plasma ß-carotene and lycopene concentrations were measured as a function of time after ip injection of carotenoids $(10 \mathrm{mg}$ $\mathrm{kg}^{-1} \mathrm{day}^{-1} \mathrm{~B}$-carotene or lycopene) in rats. The highest total plasma concentration was reached 3 and $6 \mathrm{~h}$ after $i p$ injection of lycopene or ß-carotene, respectively. After 5 days of carotenoid treatment, lycopene and $\beta$-carotene were present in the $0.10-0.51 \mathrm{nmol} / \mathrm{g}$ wet tissue range in the prostate. Using a sensitive method to detected 8-oxo-7,8dihydro-2'-deoxyguanosine (8-oxodGuo) by HPLC/EC, the level of 8 -oxodGuo in rat prostate DNA was significantly higher $(6.3 \pm 0.6$ residues $\left./ 10^{6} \mathrm{dGuo}\right) 3 \mathrm{~h}$ after Fe-NTA injection compared with control rats $\left(1.7 \pm 0.3\right.$ residues $\left./ 10^{6} \mathrm{dGuo}\right)$. Rats supplemented with lycopene or $\beta$-carotene for 5 days prior to Fe-NTA treatment showed a reduction of about 70\% in 8-oxodGuo levels to almost control levels. Compared with control rats, the prostate of Fe-NTA-treated animals showed a $78 \%$ increase in malondialdehyde accumulation. Lycopene or Bcarotene pre-treatment almost completely prevented lipid damage. Epidemiological studies have suggested a lower risk of prostate cancer in men reporting a higher consumption of tomato products. However, before associating this effect with tomato sauce constituents, more information is required. The results described here may contribute to the understanding of the protective effects of carotenoids against iron-induced oxidative stress.
\end{abstract}

\section{Introduction}

Epidemiological studies have suggested that consumption of fruits and vegetables can help cancer prevention. This effect can
Key words

- Lycopene

- ß-carotene

- DNA damage

- 8-oxo-7,8-dihydro-

2'-deoxyguanosine

- Ferric nitrilotriacetate

- Prostate cancer be attributed to a variety of compounds, such as dietary fiber, folic acid, vitamin A, and other antioxidants (vitamin C, vitamin $\mathrm{E}$, carotenoids, selenium) $(1,2)$. Because carotenoids are widely distributed in these foods, 
much interest has been focused on elucidating the molecular mechanisms responsible for their biological effects. In addition to the well-known pro-vitamin A activity of some carotenoids, part of their beneficial effects has been attributed to their antioxidant properties $(3,4)$. Their ability to scavenge free radicals (5-7) and to physically quench singlet molecular oxygen (8) has been well described. Carotenoids have also been associated with other biological mechanisms such as modulation of intercellular gap junctional communication, immune system and metabolic pathways $(9,10)$.

On the other hand, iron has been extensively reported to mediate oxidative stress (11-14). In fact, a high production of free radicals occurs in animal models of iron overload (15). Liver iron deposits are frequent in cirrhotic patients with hepatitis $\mathrm{C}$ and seem to contribute to the development of hepatocellular carcinoma (16). It has been demonstrated that the iron chelate, ferric nitrilotriacetate (Fe-NTA), is a potent inducer of lipid peroxidation in cells and in animal models (17). It has also been reported that rats intraperitoneally (ip) injected with Fe-NTA show an increase in the level of thiobarbituric acid-reactive substances in liver and an elevation of the plasma levels of aspartate aminotransferase and alanine aminotransferase indicative of hepatic injury (18). Fe-NTA causes renal carcinomas in rats (19) and induces the formation of 8-oxo7,8-dihydro-2'-deoxyguanosine (8-oxodGuo) in DNA from isolated rat kidney cells (2023). In previous studies, we have shown that lycopene can protect cultured mammalian cells against damage to biomolecules induced by Fe-NTA/ascorbate treatment (24). Furthermore, we showed a significant protective effect of lycopene against DNA oxidation, membrane damage and histopathologic changes observed in the liver of $\mathrm{Fe}$ NTA-treated rats (25).

One of the cancers which benefit from a diet rich in tomatoes and tomato products is prostate cancer (2). Recently, Boileau et al. (26) investigated the effect of tomato products or lycopene in a rat model of prostate carcinogenesis. They observed that tomato powder but not lycopene inhibited prostate carcinogenesis, suggesting that tomato products contain compounds in addition to lycopene that reduce the risk of prostate cancer. In contrast, a stimulatory effect of a lycopene oxidation product on gap junctional communication between cells was observed in rat liver epithelial WB-F344 cells, indicating a potential role of lycopene degradation products in cell signaling (27). Therefore, more information is required to elucidate the biochemical mechanisms responsible for the protective effects of lycopene. The purpose of the present study was to determine if lycopene or $ß$-carotene or both can protect against iron-induced oxidative DNA damage in the rat prostate.

\section{Material and Methods}

\section{Chemicals}

Nitrilotriacetic acid (NTA), tetrahydrofuran (THF), nuclease P1, alkaline phosphatase, ribonuclease $\mathrm{A}$ and $\mathrm{T} 1$, proteinase $\mathrm{K}$, acetonitrile, B-carotene, methanol, and isopropyl alcohol were from Sigma (St. Louis, MO, USA). All other solvents and chemicals used were of analytical grade and were supplied by Merck (Darmstadt, Germany). Water was purified with a Milli-Q system (Millipore, Bedford, MA, USA). Lycopene was donated by Dr. Zohar Nir, LycoRed Natural Products Industries Ltd. (Beer-Sheva, Israel). Fresh stock solutions of lycopene were kept in the dark and used immediately. The Fe-NTA solution was prepared just before use as described by Bates and Schlabach (28). Briefly, aqueous solutions of $\mathrm{FeCl}_{3}$ and NTA were mixed at a molar ratio of $1: 4 \mathrm{FeCl}_{3} / \mathrm{NTA}$. The $\mathrm{pH}$ of these solutions was adjusted to values ranging from 6.5 to 7.4 before use. 


\section{Lycopene or ß-carotene stock solutions}

Lycopene or $\beta$-carotene $(100 \mathrm{mg}$ ) was mixed in $2 \mathrm{~mL}$ Tween- 80 at room temperature until a homogenous paste was obtained. Physiologic saline at room temperature was added dropwise and with vigorous stirring to a final concentration of $10 \mathrm{mg}$ lycopene or Bcarotene per $\mathrm{mL}$ of suspension (29).

\section{Animal treatments}

Male Wistar rats (12 weeks old) were taken from the colony of the Instituto de Química, Universidade de São Paulo. All animals were allowed one week of in-house acclimatization with ad libitum access to standard laboratory food and water. The animals were divided into six groups of five or 10 individuals each: a) control with animals receiving ip Tween-80 in saline (vehicle); b) animals receiving ip lycopene $\left(10 \mathrm{mg} \mathrm{kg}^{-1}\right.$ day $^{-1}$ ) in vehicle, for 5 days; c) animals receiving ip $ß$-carotene in vehicle $\left(10 \mathrm{mg} \mathrm{kg}^{-1}\right.$ day $^{-1}$ ) for 5 days; d) animals receiving ip lycopene in vehicle $\left(10 \mathrm{mg} \mathrm{kg}^{-1} \mathrm{day}^{-1}\right)$ for 5 days, and after an ip Fe-NTA injection (10 $\mathrm{mg} \mathrm{Fe} / \mathrm{kg}$ ); e) animals receiving ip 3 -carotene in vehicle (10 mg kg-1 day $^{-1}$ for 5 days) and after an ip Fe-NTA injection (10 mg Fe/ $\mathrm{kg}$ ). Animals were sacrificed $3 \mathrm{~h}$ after $\mathrm{Fe}$ NTA administration and the prostate was removed, snap frozen in liquid nitrogen and stored at $-80^{\circ} \mathrm{C}$.

\section{Plasma concentration of lycopene and ß-carotene}

All rats, except the control groups, received a $1-\mathrm{mL}$ ip injection of a $10-\mathrm{mg} / \mathrm{mL}$ solution containing $\beta$-carotene or lycopene. Blood was collected from the rat tail 3, 6, 9, and $24 \mathrm{~h}$ after the injection and centrifuged to obtain plasma. Lycopene and $\beta$-carotene were analyzed by HPLC. Lycopene and Bcarotene in plasma were measured according to a previously described method $(30,31)$.
Plasma (100 $\mu \mathrm{L})$ was extracted with $100 \mu \mathrm{L}$ ethanol and $200 \mu \mathrm{L}$ hexane and samples were vortexed for $1 \mathrm{~min}$ and centrifuged for $5 \mathrm{~min}$ at $2500 \mathrm{rpm}$ and $4^{\circ} \mathrm{C}$. The upper organic phase was removed and dried in the dark under a stream of nitrogen at $30^{\circ} \mathrm{C}$. Samples were redissolved in HPLC solvent, after which $10 \mu \mathrm{L}$ of a $5-\mathrm{mM}$ solution of $\mathrm{B}$ ionone was added as internal standard. The amounts of lycopene and $\beta$-carotene were measured by HPLC using a Shimadzu HPLC system (Kyoto, Japan) equipped with two LC-10AD pumps, a Rheodyne injector and an SPD-M10AV photodiode array detector, controlled by a CBM-10A communication bus module and the CLASS LC-10AWS software. The following conditions were employed for HPLC: a reverse phase C-18 column (Spherex, 250 x $4.6 \mathrm{~mm}, 5 \mu \mathrm{m}$ ) eluted with an isocratic solvent system consisting of acetonitrile:THF:methanol (68:22: $10, \mathrm{v} / \mathrm{v} / \mathrm{v})$, with $0.025 \%(\mathrm{w} / \mathrm{v})$ ammonium acetate at $1 \mathrm{~mL} / \mathrm{min}$. Lycopene and $B$-carotene were detected at $445 \mathrm{~nm}$. The detection limit of the assay was $5 \mathrm{pmol} / \mathrm{injection}$, based on a signal-to-noise ratio of $3: 1$. The quantification limit of the assay was determined as the concentration equal to six times the value of the signal-to-noise ratio and was $7.5 \mathrm{pmol} /$ injection.

\section{Lycopene and $ß$-carotene determination in the prostate}

Carotenoids were measured in the prostate according to the method described by Zhao et al. (32). THF was added to tissue slices and the mixture was sonicated. After five extractions the extracts were dried under $\mathrm{N}_{2}$ and the residue was treated with methanolic $\mathrm{KOH}(10 \%)$ under $\mathrm{N}_{2}$ for $1 \mathrm{~h}$ at room temperature to remove lipid. The carotenoids were extracted with $1.5 \mathrm{~mL} \mathrm{NaCl}$ $(10 \%) /$ methanol and $1.5 \mathrm{~mL}$ dichloromethane. The upper organic phase was removed and dried in the dark under a stream of nitrogen at $30^{\circ} \mathrm{C}$, after which the amounts of 
lycopene and $\beta$-carotene were measured by HPLC as described above.

\section{DNA extraction and enzymatic hydrolysis}

DNA was isolated by the chaotropic $\mathrm{NaI}$ method (33). Tissue (300 mg) was suspended in $2 \mathrm{~mL}$ of a lysis solution (1\% (w/v) Triton $\mathrm{X}-100,0.32 \mathrm{M}$ sucrose, $5 \mathrm{mM}$ EDTA, 10 $\mathrm{mM}$ Tris- $\mathrm{HCl}, \mathrm{pH}$ 7.5). After centrifugation at $1500 \mathrm{~g}$ for $10 \mathrm{~min}$, the pellets were suspended in $600 \mu \mathrm{L} 10 \mathrm{mM}$ Tris- $\mathrm{HCl}$ buffer, pH 8.0, containing 5 mM EDTA, 10\% SDS and $0.15 \mathrm{mM}$ desferrioxamine. The enzymes RNase A ( $30 \mu \mathrm{L}, 1 \mathrm{mg} / \mathrm{mL})$ and RNase T1 (8 $\mu \mathrm{L}, 1000 \mathrm{U} / \mathrm{mL}$ ) in $10 \mathrm{mM}$ Tris- $\mathrm{HCl}$ buffer, $\mathrm{pH} 7.4$, containing $1 \mathrm{mM}$ EDTA and $2.5 \mathrm{mM}$ desferrioxamine, were added and the reaction mixture was incubated at $50^{\circ} \mathrm{C}$. After 15 min, $30 \mu \mathrm{L}$ proteinase $\mathrm{K}(20 \mathrm{mg} / \mathrm{mL})$ was added followed by additional incubation at $37^{\circ} \mathrm{C}$ for $1 \mathrm{~h}$. After centrifugation at $5000 \mathrm{~g}$ for $15 \mathrm{~min}$, the liquid phase was collected and $1.2 \mathrm{~mL} 7.6 \mathrm{M} \mathrm{NaI}$ was added to it, followed by the addition of $1 \mathrm{~mL}$ isopropanol. The content in the tube was mixed well by inversion until a whitish precipitate appeared. The precipitate was collected by centrifugation at $5000 \mathrm{~g}$ for $15 \mathrm{~min}$ and washed with $1 \mathrm{~mL} 40 \%$ isopropanol (w/v), followed by $1 \mathrm{~mL} 70 \%$ ethanol (w/v). After additional centrifugation at $5000 \mathrm{~g}$ for 15 $\mathrm{min}$, the DNA pellet was suspended in 100 $\mu \mathrm{L} 0.1 \mathrm{mM}$ desferrioxamine. The DNA concentration was measured spectrophotometrically at $260 \mathrm{~nm}$ and was considered to be homogeneous, $\mathrm{A}_{260} / \mathrm{A}_{280}>1.75$. DNA (100 $\mu \mathrm{g})$ was diluted in $200 \mu \mathrm{L}$ of deionized water, followed by the addition of $4 \mu \mathrm{L} 1 \mathrm{M}$ sodium acetate buffer, $\mathrm{pH}$ 5.0, containing 5 units of nuclease $\mathrm{P}_{1}$ and incubated at $37^{\circ} \mathrm{C}$ for $30 \mathrm{~min}$. Twelve microliters of $1 \mathrm{M}$ Tris- $\mathrm{HCl}$ buffer, $\mathrm{pH} 7.4,12 \mu \mathrm{L}$ phosphatase buffer, and 6 units of alkaline phosphatase were then added for an additional 1 -h incubation at $37^{\circ} \mathrm{C}$. The sample was centrifuged and the aqueous layer was collected and analyzed by HPLC.
Analysis of 8-oxo-7,8-dihydro-2'deoxyguanosine by HPLC-electrochemical detection

Samples $(100 \mu \mathrm{g})$ of digested DNA were injected into the HPLC/electrochemical detection system consisting of a Shimadzu model LC-10AD pump connected to a Luna $\mathrm{C}_{18}$ (Phenomenex, Torrance, CA, USA) reverse-phase column ( $250 \times 4.6 \mathrm{~mm}$ ID, particle size $5 \mu \mathrm{m})$. The flow rate of the isocratic eluent $(50 \mathrm{mM}$ potassium phosphate buffer, $\mathrm{pH} 5.5$, and $8 \%$ methanol) was $1 \mathrm{~mL} / \mathrm{min}$. Coulometric detection was obtained with a Coulochem II detector (ESA, Chemsford, MA, USA). The potentials of the two electrodes were set at 120 and $280 \mathrm{mV}$. Elution of unmodified nucleosides was monitored simultaneously with a Shimadzu SPD-10A UV detector set at $254 \mathrm{~nm}$. A Shimadzu Class-LC10 1.6 software was used to calculate the peak areas. The molar ratio of 8oxodGuo to dGuo in each DNA sample was determined based on coulometric detection at $280 \mathrm{mV}$ for 8-oxodGuo and on absorbance at $254 \mathrm{~nm}$ for dGuo in each injection.

\section{Malondialdehyde determination}

Malondialdehyde (MDA) was measured as described (34). Briefly, an aqueous sample containing MDA at $\mathrm{pH}$ 6.5-8.0 was separated by HPLC using an aminophase column (S-5 Spherisorb- $\mathrm{NH}_{2}$ ) with acetonitrile $30 \mathrm{mM}$ Tris buffer, $\mathrm{pH} 7.4(1: 9, \mathrm{v} / \mathrm{v})$, as the mobile phase at $1 \mathrm{~mL} / \mathrm{min}$. The effluent was monitored at 267 $\mathrm{nm}$, the molar absorptivity $(\varepsilon)$ of the enolate anion form of free MDA, was taken to be 31,500 at $\mathrm{pH}$ 7.4. To deproteinize the sample, $300 \mathrm{mg}$ of the tissue was mixed with an equal volume of acetonitrile followed by centrifugation. A $20-\mu \mathrm{L}$ aliquot of the supernatant was injected into the HPLC apparatus.

\section{Statistical analysis}

Data are reported as means \pm SEM and 
were analyzed by two-way ANOVA followed by the post hoc Bonferroni test performed using GraphPad Prism version 4.02 for Windows (GraphPad Software, San Diego, CA, USA) to compare groups or by the Student $t$-test when two groups were compared. Differences were considered significant at $\mathrm{P}<0.05$.

\section{Results and Discussion}

Oxidative damage to biomolecules has been postulated to be involved in several chronic diseases (35). Iron is a well-known inducer of oxidative stress. The administration of Fe-NTA to rats and mice causes in vivo oxidative DNA damage. It has been reported that all four DNA bases are modified in the renal chromatin of rats within 24 $\mathrm{h}$ of Fe-NTA administration (22). Prostate tissue is vulnerable to oxidative stress (36) and whether carotenoids can protect against DNA damage and lipoperoxidation associated with this process is of particular interest.

Plasma $\beta$-carotene and lycopene concentrations, measured as a function of time after $10 \mathrm{mg}$ of ip injection of the carotenoid in rats, are shown in Figure 1. The highest concentration of $\beta$-carotene in plasma, 4.05 $\pm 0.84 \mathrm{nmol} / \mathrm{mL}$, was reached after $6 \mathrm{~h}$, remaining at this level for another $3 \mathrm{~h}$ (Figure 1A). Rats injected with the same amount of lycopene displayed a four-fold lower plasma carotenoid concentration peak $(0.97$ $\pm 0.16 \mathrm{nmol} / \mathrm{mL}$ blood) than those injected with $B$-carotene (Figure 1B). The maximum plasma lycopene level was observed $3 \mathrm{~h}$ after administration. The control animals, which did not receive carotenoid treatment, displayed no detectable plasma lycopene or $ß$-carotene. Therefore, the carotenoid concentration used in this study for the treatment of rats effectively raised plasma concentrations.

To provide additional support for the hypothesis that increased carotenoid con- centration protects in vivo against oxidative damage, membrane and DNA damage was evaluated in prostate tissue. Carotenoid levels in the prostate of rats treated for 5 consecutive days with ip injections of $10 \mathrm{mg} / \mathrm{kg}$ body weight lycopene or $\beta$-carotene were: $0.51 \pm 0.04 \mathrm{nmol}$ lycopene/g wet tissue and $0.13 \pm 0.01 \mathrm{nmol} \beta$-carotene $/ \mathrm{g}$ wet tissue for the lycopene and $B$-carotene treatments, re-

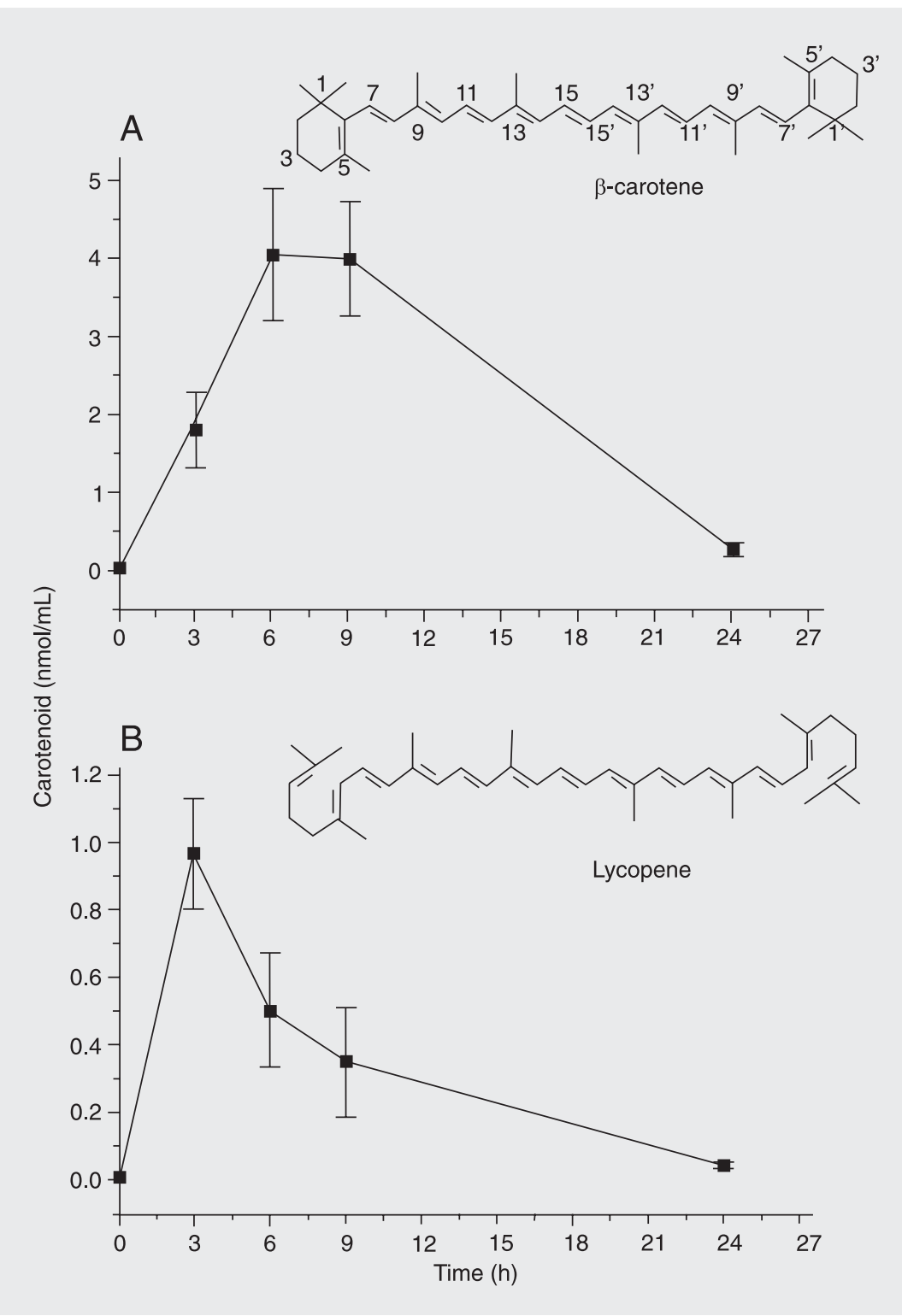

Figure 1. Plasma carotenoid concentration as a function of time. Data are reported as means \pm SEM for 5 rats in each group. A, B-carotene levels. $B$, Lycopene levels. Blood was collected from rats supplemented with B-carotene or lycopene (1-mL ip injection of a 10-mg/ $\mathrm{mL}$ solution) and analyzed by HPLC-electrochemical detection. 
spectively. Lycopene or ß-carotene were not detected in prostate tissue of control rats (data not shown).

Treatment with Fe-NTA caused substantial lipid peroxidation in rat prostate tissue as indicated by MDA formation (Table 1). MDA levels were $817 \pm 122 \mathrm{nmol} / \mathrm{g}$ tissue $3 \mathrm{~h}$ after Fe-NTA administration. Carotenoid-supplemented rats showed inhibition of MDA formation to control levels $(364 \pm 17 \mathrm{nmol} / \mathrm{g}) 3$

Table 1. Lycopene and B-carotene supplementation block the increase of MDA content of rat prostate tissue after Fe-NTA treatment.

MDA (nmol/g protein)

\begin{tabular}{ll}
\hline Control & $359 \pm 32^{\mathrm{b}}$ \\
Lycopene (5 days) & $363 \pm 30$ \\
B-carotene (5 days) & $367 \pm 13$ \\
Fe-NTA ( 3 h) & $817 \pm 122^{\mathrm{a}, \mathrm{b}}$ \\
Lycopene + Fe-NTA (3 h) & $364 \pm 17^{\mathrm{a}}$ \\
B-carotene + Fe-NTA (3 h) & $377 \pm 36^{\mathrm{a}}$
\end{tabular}

Each value represents the mean \pm SEM of 5 animals. Saline-treated animals served as control. Lycopene or ß-carotene (10 mg/kg body weight) was administered for 5 consecutive days before Fe-NTA ( $10 \mathrm{mg} / \mathrm{kg}$ body weight) treatment. MDA = malondialdehyde; Fe-NTA = ferric nitrilotriacetate. ap $<0.001$ compared to the Fe-NTA group; bP $<$ 0.005 compared to control (Student $t$-test).

Table 2. Lycopene and B-carotene supplementation block the increase in 8-oxodGuo content of prostate DNA of rats after Fe-NTA treatment.

8-oxodGuo (residues $/ 10^{6} \mathrm{dGuo}$ )

\begin{tabular}{ll}
\hline Control & $1.7 \pm 0.3^{\mathrm{b}}$ \\
Lycopene & $2.1 \pm 0.4^{\mathrm{b}}$ \\
B-carotene & $2.3 \pm 0.5$ \\
Fe-NTA & $6.3 \pm 0.6^{\mathrm{a}, \mathrm{b}}$ \\
Lycopene + Fe-NTA & $1.8 \pm 0.3^{\mathrm{a}}$ \\
B-carotene + Fe-NTA & $1.9 \pm 0.2^{\mathrm{a}}$ \\
\hline
\end{tabular}

Each value represents the mean \pm SEM of 5 animals. Lycopene or B-carotene $(10 \mathrm{mg} / \mathrm{kg}$ body weight, ip) was administered for 5 days prior to Fe-NTA (10 mg Fe/kg body weight, ip). 8-oxodGuo = 8-oxo-7,8-dihydro-2'-deoxyguanosine; FE-NTA $=$ ferric nitrilotriacetate.

aP $<0.001$ compared to the Fe-NTA group; ${ }^{\text {b }}<$ 0.005 compared to control (Student $t$-test). $\mathrm{h}$ after Fe-NTA treatment for rats pre-treated with lycopene and with $\beta$-carotene (377 \pm 36 $\mathrm{nmol} / \mathrm{g}$ ). B-Carotene pre-treatment almost completely prevented Fe-NTA-induced membrane damage, as indicated by MDA formation.

The steady state level of 8-oxodGuo was quantified using a sensitive HPLC-electrochemical detection method. The level of 8oxodGuo in rat prostate DNA was significantly higher $\left(6.3 \pm 0.6\right.$ residues $\left./ 10^{6} \mathrm{dGuo}\right)$ $3 \mathrm{~h}$ after Fe-NTA administration compared with control rats $\left(1.7 \pm 0.3\right.$ residues $/ 10^{6}$ dGuo). Rats supplemented with lycopene or B-carotene for 5 days prior to Fe-NTA treatment showed a reduction of approximately $70 \%$ in the 8-oxodGuo levels to almost control levels (Table 2). In fact, a large body of other evidence points to the role of oxidative DNA damage in carcinogenesis (1). Induction of G:C to T:A transversion by 8-oxodGuo can activate the ras oncogene by point mutation (37). The measurement of 8-oxodGuo in DNA has been indicated as a feasible marker to investigate the antioxidant properties of food constituents in vivo (38).

Using statistical analyses of Fourier transform-IR spectra, Malins et al. (39) reported that DNA of histologically normal human prostates undergo structural changes in the bases and backbone with increasing age. Of the older men, $42 \%$ exhibited a DNA phenotype mimicking that of primary prostate tumors. Significantly higher levels of 8oxodGuo were found in prostate DNA of older men (ages 55-80 years) compared with younger men (age 16-36 years). The authors suggested that hydroxyl radicals contributed to the structural changes that characterize the cancer-like phenotype (39).

The effect of consumption of tomato sauce-based pasta dishes on lycopene uptake, oxidative DNA damage, and prostatespecific antigen was reported by Chen et al. (36) in patients diagnosed with prostate cancer. The levels of 8-oxodGuo were significantly lower in the group consuming tomato 
dishes for 3 weeks than in randomly selected patients, and serum prostate-specific antigen also decreased after this dietary intervention. These data indicate the possible application of tomato sauce constituent, possibly lycopene, in the treatment of prostate cancer.

Although epidemiological data show the association between carotenoids and health protection, the antioxidant properties of these compounds are still debatable. The data re- ported here, using iron as a model of oxidative stress generation in vivo, indicate clearly that $\beta$-carotene or lycopene provides strong protection against membrane and DNA oxidation in the prostate induced by iron treatment. The present results support the in vivo antioxidant effect of carotenoids and provide evidence to explain part of the beneficial effects of tomato products reported in epidemiological trials.

\section{References}

1. Ames BN, Gold LS \& Willett WC (1995). The causes and prevention of cancer. Proceedings of the National Academy of Sciences, USA, 995: 5258-5265.

2. Giovannucci E (1999). Tomatoes, tomato-based products, lycopene, and cancer: Review of the epidemiologic literature. Journal of the National Cancer Institute, 91: 317-331.

3. Stahl W \& Sies H (1996). Lycopene: A biologically important carotenoid for humans? Archives of Biochemistry and Biophysics, 336: 1-9.

4. Kiokias S \& Gordon MH (2004). Antioxidant properties of carotenoids in vitro and in vivo. Food Reviews International, 20: 99-121.

5. Kennedy TA \& Lieber DC (1992). Peroxyl radical scavenging by beta-carotene in lipid bilayers - effect of oxygen partial-pressure. Journal of Biological Chemistry, 267: 4658-4663.

6. Palozza P, Moualla S \& Krinsky NI (1992). Effects of beta-carotene and alpha-tocopherol on radical-initiated peroxidation of microsomes. Free Radical Biology and Medicine, 13: 127-136.

7. Terao J (1989). Antioxidant activity of beta-carotene-related carotenoids in solution. Lipids, 24: 659-661.

8. Di Mascio P, Kaiser S \& Sies H (1989). Lycopene as the most efficient biological carotenoid singlet oxygen quencher. Archives of Biochemistry and Biophysics, 274: 532-538.

9. Rao AV \& Agarwal S (2000). Role of antioxidant lycopene in cancer and heart disease. Journal of the American College of Nutrition, 19: 563-569.

10. Stahl W, von Laar J, Martin H-D et al. (2000). Stimulation of gap junctional communication: Comparison of acyclo-retinoic acid and lycopene. Archives of Biochemistry and Biophysics, 373: 271-274.

11. Meneghini R (1997). Iron homeostasis, oxidative stress, and DNA damage. Free Radical Biology and Medicine, 23: 783-792.

12. Dreher D \& Junod AF (1996). Role of oxygen free radicals in cancer development. European Journal of Cancer, 32: 30-38.

13. Ames BN (1983). Dietary carcinogens and anticarcinogens-oxygen radicals and degenerative diseases. Science, 221: 1256-1264.

14. Valko M, Morris H \& Cronin MTD (2005). Metals, toxicity and oxidative stress. Current Medicinal Chemistry, 12: 1161-1208.

15. Stohs SJ \& Bagchi D (1995). Oxidative mechanisms in the toxicity of metal ions. Free Radical Biology and Medicine, 18: 321-336.

16. Chapoutot C, Esslimani M, Joomaye Z et al. (2000). Liver iron excess in patients with hepatocellular carcinoma developed on viral C cirrhosis. Gut, 46: 711-714.
17. Toyokuni S (1996). Iron-induced carcinogenesis: The role of redox regulation. Free Radical Biology and Medicine, 20: 553-556.

18. Suzumura K, Hashimura Y, Kubota $\mathrm{H}$ et al. (2000). Antioxidative property of T-0970, a new ureidophenol derivative. Free Radical Biology and Medicine, 32: 255-264.

19. Ebina Y, Okada S, Hamazaki S et al. (1986). Nephrotoxicity and renal cell carcinoma after use of iron- and aluminum-nitrilotriacetate complexes in rats. Journal of the National Cancer Institute, 76: 107113.

20. Umemura T, Sai K, Takagi A et al. (1990). Formation of 8-hydroxydeoxyguanosine (8-OH-dG) in rat kidney DNA after intraperitoneal administration of ferric nitrilotriacetate (Fe-NTA). Carcinogenesis, 11: 345-347.

21. Yamaguchi R, Hirano T, Asami S et al. (1996). Increased 8hydroxyguanine levels in DNA and its repair activity in rat kidney after administration of a renal carcinogen, ferric nitrilotriacetate. Carcinogenesis, 17: 2419-2422.

22. Toyokuni S, Mori T \& Dizdaroglu M (1994). DNA base modifications in renal chromatin of Wistar rats treated with a renal carcinogen, ferric nitrilotriacetate. International Journal of Cancer, 57: 123-128.

23. Kawanishi S, Hiraku Y, Murata M et al. (2002). The role of metals in site-specific DNA damage with reference to carcinogenesis. Free Radical Biology and Medicine, 32: 822-832.

24. Matos HR, Di Mascio P \& Medeiros MHG (2000). Protective effect of lycopene on lipid peroxidation and oxidative DNA damage in cell culture. Archives of Biochemistry and Biophysics, 383: 56-59.

25. Matos HR, Capelozzi VL, Gomes OF et al. (2001). Lycopene inhibits DNA damage and liver necrosis in rats treated with ferric nitrilotriacetate. Archives of Biochemistry and Biophysics, 396: 171-177.

26. Boileau TWM, Liao ZM, Kim S et al. (2003). Prostate carcinogenesis in N-methyl-N-nitrosourea (NMU)-testosterone-treated rats fed tomato powder, lycopene, or energy-restricted diets. Journal of the National Cancer Institute, 95: 1578-1586.

27. Aust O, Ale-Agha N, Zhang L et al. (2003). Lycopene oxidation product enhances gap junctional communication. Food and Chemical Toxicology, 41: 1399-1407.

28. Bates GW \& Schlabach MR (1973). The reaction of ferric salts with transferrin. Journal of Biological Chemistry, 248: 3228-3232.

29. Forssberg A, Lingen C, Ernst L et al. (1959). Modification of the Xirradiation syndrome by lycopene. Experimental Cell Research, 16: 7-14. 
30. Riso P, Pinder A, Santangelo A et al. (1999). Does tomato consumption effectively increase the resistance of lymphocyte DNA to oxidative damage? American Journal of Clinical Nutrition, 69: 712-718.

31. Lowe GM, Booth LA, Young AJ et al. (1999). Lycopene and Bcarotene protect against oxidative damage in HT29 cells at low concentrations but rapidly lose this capacity at higher doses. Free Radical Research, 30: 141-151.

32. Zhao Z, Khachik F, Richie JP et al. (1998). Lycopene uptake and tissue disposition in male and female rats. Proceedings of the Society for Experimental Biology and Medicine, 218: 109-114.

33. Wang L, Hirayasu K, Ishizawa M et al. (1994). Purification of genomic DNA from human whole blood by isopropanol-fractionation with concentrated Nal and SDS. Nucleic Acids Research, 22: 17741775.

34. Esterbauer H \& Cheeseman KH (1990). Determination of aldehydic lipid peroxidation products: malondialdehyde and 4-hydroxynonenal. Methods in Enzymology, 186: 407-421.

35. Willkox JK, Ash SL \& Catignani GL (2004). Antioxidants and prevention of chronic disease. Critical Reviews in Food Science and Nutri- tion, 44: 275-295.

36. Chen L, Stacewicz-Sapuntzakis M, Duncan C et al. (2001). Oxidative DNA damage in prostate cancer patients consuming tomato sauce-based entrees as a whole-food intervention. Journal of the National Cancer Institute, 93: 1872-1879.

37. Higinbotham KG, Rice JM, Diwan BA et al. (1992). GGT to GTT transversions in codon 12 of the K-ras oncogene in rat renal sarcomas induced with nickel subsulfide or nickel subsulfide/iron are consistent with oxidative damage to DNA. Cancer Research, 52 : 4747-4751.

38. Halliwell B (1999). Oxygen and nitrogen are pro-carcinogens, damage to DNA by reactive oxygen, chlorine and nitrogen species: measurement, mechanism and the effects of nutrition. Mutation Research - Genetic Toxicology and Environmental Mutagenesis, 443: 37-52.

39. Malins DC, Johnson PM, Barker EA et al. (2003). Cancer-related changes in prostate DNA as men age and early identification of metastasis in primary prostate tumors. Proceedings of the National Academy of Sciences, USA, 100: 5401-5406. 